\title{
Characterization of MDCK cells and evaluation of their ability to respond to infectious and non-infectious stressors
}

\author{
Francesca Maria Capellini • Walter Vencia • Massimo Amadori • \\ Giulia Mignone · Erica Parisi · Lucia Masiello • Barbara Vivaldi • \\ Angelo Ferrari $\cdot$ Elisabetta Razzuoli 1
}

Received: 23 May 2019/Accepted: 28 November 2019/Published online: 4 December 2019

(C) Springer Nature B.V. 2019

\begin{abstract}
The Madin-Darby Canine Kidney (MDCK) cell line is widely used as epithelial cell model in studies ranging from viral infection to environmental pollutants, and vaccines production. However, little is known about basal expression of genes involved in innate immunity, and the ability to respond to infectious and non-infectious stressors. Therefore, the aims of our study were to evaluate the basal level of expression of pivotal genes in the innate immune response and cell cycle regulation, as well as to evaluate the ability of this cell line to respond to
\end{abstract}

F. M. Capellini · G. Mignone · E. Parisi

Laboratory of Diagnostic, Istituto Zooprofilattico

Sperimentale del Piemonte, Liguria e valle d'Aosta, S.S

Genova, piazza Borgo pila 24-39, 16129 Genoa, Italy

W. Vencia · A. Ferrari · E. Razzuoli $(\bowtie)$

National Reference Center of Veterinary and Comparative

Oncology (CEROVEC), Istituto Zooprofilattico

Sperimentale del Piemonte, Liguria e valle d'Aosta, piazza Borgo pila 24-39, 16129 Genoa, Italy

e-mail: elisabetta.razzuoli@izsto.it

M. Amadori

Laboratory of Cellular Immunology, Istituto

Zooprofilattico Sperimentale della Lombardia e

dell'Emilia-Romagna, via A. Bianchi 9, 25124 Brescia, Italy

L. Masiello · B. Vivaldi

Laboratory of Chemistry, Istituto Zooprofilattico

Sperimentale del Piemonte, Liguria e valle d'Aosta,

piazza Borgo pila 24-39, 16129 Genoa, Italy infectious or non-infectious stressors. As surmised in our working hypothesis, we demonstrated the constitutive expression of genes involved in the innate immune response and cell defense alike, including TLRs, Interleukins, Myd88, $p 65 / N F-k B$ and $p 53$. Moreover, we described the ability of this cell line to respond to LPS and cadmium $(\mathrm{Cd} 2+)$ in terms of gene expression and cytokine release. These data confirm the possibility of using this cell line as a model in studies of host/pathogen interaction and response to non-infectious stressors.

Keywords MDCK · Gene expression - Cytokines · Innate immunity $\cdot \mathrm{Cd} 2+\cdot$ LPS

\section{Introduction}

The Madin-Darby Canine Kidney (MDCK) cell line is widely used as epithelial cell model. Indeed, its properties of apico-basolateral polarity, cell junctions and in vitro growth rate are well known (Dukes et al. 2012). MDCK cells are also used in studies of viral infections, and more recently in vaccine production (Gregersen et al. 2011). However, little is known about basal expression of genes involved in innate immunity, DNA repair, cell cycle regulation, as well as in the secretion of cytokines, and the response to infectious and non-infectious stressors. Moreover, no 
data are available about the effect of cell passages and aging of confluent monolayers. These gaps may hinder a correct use of these cells for vaccine production and studies on host/pathogen interaction. Owing to the above, the aims of our study were: 1-to evaluate the basal level of expression of pivotal genes in the innate immune response and cell cycle regulation. 2-to evaluate the ability of this cell line to respond to infectious or non-infectious stressors.

In our study we decided to consider cell monolayer aging, a concept differing from cellular senescence; indeed, whereas the phenomenon known as replicative senescence is due to the ability of cells obtained from primary cultures to reduce their number of divisions until a complete stop within few weeks of culture (Ogrodnik et al. 2019), an immortalized cell line can indefinitely replicate in the presence of satisfactory environmental conditions (e.g. nutrients, temperature). However, after monolayer confluence the concentration of Damage-associated molecular patterns (DAMPs, such as self DNA) in supernatants can increase and cause changes of gene expression; indeed sensing such DNAs leads to activation of interferon regulatory factor 3 (IRF3) and nuclear factor kappa B (NF-kB), respectively (Sok et al. 2018).

In this study, we chose cadmium $(\mathrm{Cd} 2+)$ as a noninfectious stressor. This heavy metal is widely known for its toxic and carcinogenic effects. $\mathrm{Cd} 2+$ toxicity has now been shown in nearly every organ and tissue of the body and the kidney is a critical organ for $\mathrm{Cd} 2+$ accumulation and toxicity. Indeed, exposure to $\mathrm{Cd} 2+$ has been implicated in renal dysfunction (Bernard 2008). Many studies demonstrated the ability of $\mathrm{Cd} 2+$ to modulate the activity of cellular enzymes, to suppress mitochondrial functions, to initiate oxidative stress, and to disrupt calcium homeostasis (Tchounwou et al. 2012; Rusanov et al. 2015). Moreover, in our previous study we demonstrated the ability of this heavy metal to modulate innate immune responses in IPEC-J2 cells as a function of both time and concentration (Razzuoli et al. 2018). Furthermore, Cd2+ exposure has been reported to alter a variety of immune cell functions in terms of both protein expression patterns and immune cell functions (Maret and Moulis 2013). The major mechanism behind $\mathrm{Cd} 2+$ toxicity is oxidative stress that induces damages in organs such as kidney, liver, lung, brain and testis. This is due to the inflammatory response caused by Cd-driven tissue damage, including leukocyte activation and recruitment. In particular, $\mathrm{Cd} 2+$ induces expression of IL-1 $\beta$, TNF- $\alpha$, IL-6, IL-8, which underlies the amplification of the inflammatory response (Milnerowicz et al. 2015). Moreover, low levels of $\mathrm{Cd} 2+$ may be present in environment contaminants like dust (Tan et al. 2016), plastic and glass (Turner 2019).

To mimic infectious stressors, we chose Lipopolysaccharide (LPS), present in the external wall of Gram-negative bacteria and largely responsible for their toxicity. LPS is recognized by TLR4-coreceptors MD2 and CD14, which recognize the lipid A core of LPS. TLR4 transduces the signal via MyD88 and TRIF adapters to activate NF- $\kappa \mathrm{B}-$ and/or IRF3mediated transcription of genes encoding pivotal molecules of the immune system, including cytokines and chemokines, which mimics major inflammatory response models (Poltorak et al. 1998; Rathinam et al. 2019). Moreover, LPS is of concern since it is a common contaminant of cell cultures. It is an amphipathic molecule which adheres to hydrophobic materials like plastics and glassware. Therefore, crosscontamination between experiments might occur if LPS molecules were not effectively removed. If LPS is introduced into laboratory equipment, its persistence can determine a memory effect provoking inflammatory responses or endotoxin tolerance. The control of LPS contamination is difficult due to its ubiquity in nature, toxicity and stability in solutions (stable depending on $\mathrm{pH}$, ions and surfactants), and even sterilization at temperatures $>180{ }^{\circ} \mathrm{C}$ (Gorbet and Sefton 2005). This can cause contamination or crosscontamination between experiments if LPS is not effectively removed from the system (Schwarz et al. 2014).

As for the relevance of our study, MDCK cells are widely used in many laboratories for viral isolation, vaccine development and production; furthermore, as they derive from renal tubule cells, they can be used in vitro to evaluate host-pathogen and host-chemical interaction. In this study, for the first time the basal expression of genes involved both in the inflammatory response and in the cell cycle was evaluated; furthermore, we investigated the effects of passage level and aging on the expression of the same genes. These parameters can affect the expression of cytokines, as shown, e.g. in IPEC-J2 cells (Razzuoli et al. 2013). Furthermore, we evaluated the ability of MDCK cells to interact with stressors of various nature. 


\section{Materials and methods}

Cell culture

MDCK cells (Madin-Darby Canine Kidney, IZSLER biobank OIE code BS CL 64) were grown in Minimum Essential Medium (MEM, Carlo Erba Reagents S.r.l., Milano, cat FA30WL0440500) enriched with 10\% (v/ v) fetal calf serum $\left(\mathrm{FCS}, \mathrm{GIBCO}^{\mathrm{TM}}\right.$, Thermofisher scientific, Milano, cat 10437-036) and a mixture of antibiotics (penicillin and streptomycin, $1 \% \mathrm{v} / \mathrm{v}$, Carlo Erba Reagents S.r.l., Milano, cat FA30WL0022100). Cells were seeded into 12-well tissue culture plates ( $2 \mathrm{ml}$ per well, $2.5 \times 10^{5}$ cells $/ \mathrm{ml}$ ) and incubated at $37{ }^{\circ} \mathrm{C}$ in $5 \% \mathrm{CO}_{2}$ until confluence (16-22 h). Cells were tested at the 33rd, 34th and 40th passages; then, cells at confluence (40th passage) were further incubated for $24 \mathrm{~h}$ to evaluate the effects of aging. Each experiment was repeated ten times.

Cadmium treatment

Monolayer cells were treated with $20 \mu \mathrm{M}$ Cadmium (Carlo Erba reagents srl, Milano, cat 505548). The choice of the exposure level was based on a previous study that defined low and moderate cadmium exposure levels (Luevano and Damodaran 2014). In our study, we treated MDCK with $20 \mu \mathrm{M} \mathrm{Cd} 2+$, which was equivalent to $1.9 \%$ of the $4-\mathrm{h}$ DL100 $(105 \mathrm{mg} / \mathrm{kg})$ value after oral administration in dogs (Venugopal and Luckey 1975). Cd2 + was dissolved in MEM, and cells were stimulated for 3 or $24 \mathrm{~h}$ at $37{ }^{\circ} \mathrm{C}$ in $5 \% \mathrm{CO}_{2}$. We set up 3 biological replicates; cells treated with medium only were used as negative control (3 biological replicates, as well). Each experiment was performed trice.

$\mathrm{Cd} 2+$ uptake

We tested the ability of MDCK to adsorb $\mathrm{Cd} 2+$ at different times after exposure: 1, 3 and $24 \mathrm{~h}$. Cells were treated with $20 \mu \mathrm{M}$ Cadmium $\left(4 \mu \mathrm{g} / 10^{6}\right.$ cells $)$; then, intracellular concentration of $\mathrm{Cd} 2+$ at different time of exposure was checked using a Graphite Furnace Atomic Absorption Spectroscopy (model ZEEnit 650 P, Analytik-Jena, Germany) as previously described (Razzuoli et al. 2018). Each Cd2+ concentration was checked in quintuplicate and intracellular $\mathrm{Cd} 2+$ was expressed as $\mu \mathrm{g} \mathrm{Cd} 2+/ 10^{6}$ cells.
Lps treatment

Monolayer cells were treated with $1 \mu \mathrm{g} / \mathrm{mL}$ LPS from E. coli O111:B4 (Sigma-Aldrich, Inc., Milano, cat L4391). LPS was dissolved in MEM, and cells were stimulated for 3 or $24 \mathrm{~h}$ at $37{ }^{\circ} \mathrm{C}$ in $5 \% \mathrm{CO}_{2}$. We set up 3 biological replicates; cells treated with medium only were used as negative control (3 repeats). Each experiment was performed thrice.

\section{Gene expression}

In this study, we evaluated the expression of the following genes in untreated cells: TNF- $\alpha$, iNOS, STAT-5a, IFN- $\gamma$, IL1- $\beta$, IL-2, IL-4, IL-5, IL-6, IL-8, IL-10, IL-12, IL-15, IL-16, IL-17, IL-18, IL-23, IL-27, MYD88, NF-kB/p65, TLR1, TLR2, TLR3, TLR4, TLR5, TLR7, TLR8, TLR9, TLR10, MD2, CD14, CD44, CXCR4, RAD51, p53, HPRT1, PTEN, ErbB2, B2M, GAPDH, ACTB. To this purpose, we used primer sets described in previous studies (Table 1), as well as others (Table 1) designed in our laboratory using the BLAST function of PUBMED (https://www. ncbi.nlm.nih.gov/tools/primer-blast/index.cgi?LINK_ LOC=BlastHome). The expression of the above genes was assessed by RT-qPCR Total RNA was extracted from MDCK cells using RNeasy Mini Kit (Qiagen, Milano, cat No 74106) using DNase digestion protocol, RNA concentration was evaluated by UV absorbance (Biophotometer, Eppendorf, Milan) and $30 \mathrm{ng}$ of RNA (10 $\mathrm{ng} / \mu \mathrm{l})$ were added to the reaction mix for cDNA synthesis as previously described (Razzuoli et al. 2011). EVA Green RT-qPCR amplification were performed a CFX96 ${ }^{\mathrm{TM}}$ Real-Time System (Bio-Rad, Milano) as previously described (Razzuoli et al. 2014). To evaluate the basal level of expression, PCRnegative samples were given a $\mathrm{Ct} 39$ fictitious value, whereas the positive ones showed $\mathrm{Ct}$ values $<38$. After LPS or $\mathrm{Cd} 2+$ treatment we evaluated the expression of the following genes: IL-8, IL-6, IL-1 $\beta$, TLR1, TLR3, TLR5, TLR9, iNOS, CD14, MyD88, NF-kB/p65, TLR4, MD2, IL-18. To normalize the results, we tested B2M, B-ACT, HPRT1 and GAPDH as possible housekeeping genes by NormFinder algorithm (Peletto et al. 2011). In each sample, the relative expression of the selected genes was calculated using the formula $2^{-\Delta \Delta \mathrm{Ct}}$, where $\mathrm{Ct}$ is short for cycle of threshold and $\Delta \mathrm{Ct}=\mathrm{Ct}$ (target gene) $-\mathrm{Ct}$ (housekeeping). $\Delta \mathrm{Ct}$ values are the mean of three test 
Table 1 Primer sets for Evagreen quantitative, RT Real-Time PCR amplification of canine genes

\begin{tabular}{|c|c|c|c|}
\hline Gene & Primer & & Source \\
\hline \multirow[t]{2}{*}{ B2M } & Forward & TCCTCATCCTCCTCGCT & Selvarajah et al. (2017) \\
\hline & Reverse & CCTGCTCATTGGGAGTGAA & \\
\hline \multirow[t]{2}{*}{ ACTB } & Forward & ACGGAGCGTGGCTACAGC & Sauter et al. (2005) \\
\hline & Reverse & TCCTGATGTCACGCACGA & \\
\hline \multirow[t]{2}{*}{ GADPH } & Forward & TTCCACGGCACAGTCAAG & Menezes-Souza et al. (2011) \\
\hline & Reverse & ACTCAGCACCAGCATCAC & \\
\hline \multirow[t]{2}{*}{ IL1- $\beta$} & Forward & TGCAAAACAGATGCGGATAA & Jalilian et al. (2012) \\
\hline & Reverse & GTAACTTGCAGTCCACCGATT & \\
\hline \multirow[t]{2}{*}{ IL-2 } & Forward & ССТCAACTCCTGCCACAATGT & Kim et al. (2013) \\
\hline & Reverse & TGCGACAAGTACAAGCGTCAGT & \\
\hline \multirow[t]{2}{*}{ IL-4 } & Forward & TGCAGAGCTGCTACTGTACTGCGGC & Peeters et al. (2005) \\
\hline & Reverse & CATGCTGCTGAGGTTCCTGT & \\
\hline \multirow[t]{2}{*}{ IL-5 } & Forward & GCCTATGTTTCTGCCTTTGC & Menezes-Souza et al. (2011) \\
\hline & Reverse & GGTTCCCATCGCCTATCA & \\
\hline \multirow[t]{2}{*}{ IL-6 } & Forward & TCCAGAACAACTATGAGGGTGA & Cavalcanti et al. (2015) \\
\hline & Reverse & TCCTGATTCTTTACCTTGCTCTT & \\
\hline \multirow[t]{2}{*}{ IL-8 } & Forward & TGATTGACAGTGGCCCACATTGTG & This paper \\
\hline & Reverse & GTCCAGGCACACCTCATTTC & \\
\hline \multirow[t]{2}{*}{ IL-10 } & Forward & CGACCCAGACATCAAGAACC & Peeters et al. (2005) \\
\hline & Reverse & CACAGGGAAGAAATCGGTGA & \\
\hline \multirow[t]{2}{*}{ IL-12 } & Forward & TGGAGGTCAGCTGGGAATACC & Sauter et al. (2005) \\
\hline & Reverse & TGCAAAATGTCAGGGAGAAGTA & \\
\hline \multirow[t]{2}{*}{ IL-15 } & Forward & ACTTGCATCCAGTGCTACTT & Choi et al. (2006) \\
\hline & Reverse & CGAGCGAGATAACACCTAAC & \\
\hline \multirow[t]{2}{*}{ IL-16 } & Forward & CCAGTCCAAGGGGATTACAG & Vanherberghen et al. (2012) \\
\hline & Reverse & TGAGAATGAGCGGTTGTG & \\
\hline \multirow[t]{2}{*}{ IL-17 } & Forward & ACTCCAGAAGGCCCTCAGATTA & Nascimento et al. (2015) \\
\hline & Reverse & GATTCCAAGGTGAGGTAGATCG & \\
\hline \multirow[t]{2}{*}{ IL-18 } & Forward & СТCTCCTGTAAGAACAAAACTATTTCCTT & Kurata et al. (2004) \\
\hline & Reverse & GAACACTTCTCTGAAAGAATATGATGTCA & \\
\hline \multirow[t]{2}{*}{ IL-23 } & Forward & ACAGAACGGACAGCATCAGG & This paper \\
\hline & Reverse & CGCTGCCTGCTTCTCAAATC & \\
\hline \multirow[t]{2}{*}{ IL-27 } & Forward & TTACTGCTCTCCCTGCTCCT & This paper \\
\hline & Reverse & TTGAACTCCCTCCGCAACTC & \\
\hline \multirow[t]{2}{*}{$\mathrm{TNF}-\alpha$} & Forward & CGTCCATTCTTGCCCAAAC & Menezes-Souza et al. (2011) \\
\hline & Reverse & AGCCCTGAGCCCTTAATTC & \\
\hline \multirow[t]{2}{*}{ IFN- $\gamma$} & Forward & CCAGATCATTCAAAGGAGCA & Cavalcanti et al. (2015) \\
\hline & Reverse & CGTTCACAGGAATTTGAATCAG & \\
\hline \multirow[t]{2}{*}{ TLR1 } & Forward & GGTCCATAAGCGCAGGGAAT & This paper \\
\hline & Reverse & TGCAGGATAACGGAGACACG & \\
\hline \multirow[t]{2}{*}{ TLR2 } & Forward & AACGCTTTCTCGAAGGAGCA & This paper \\
\hline & Reverse & AGTGGCACAGGTAGTCCTCT & \\
\hline \multirow[t]{2}{*}{ TLR3 } & Forward & TGTCACTTGCTCAGTCTCCTTT & Hosein et al. (2015) \\
\hline & Reverse & GTCCAATTTCATTAAGGCCAAG & \\
\hline
\end{tabular}


Table 1 continued

\begin{tabular}{|c|c|c|c|}
\hline Gene & Primer & & Source \\
\hline \multirow[t]{2}{*}{ TLR4 } & Forward & GCTGGATGGTAAACCGTGGA & This paper \\
\hline & Reverse & AGCACAGTGGCAGGTACATC & \\
\hline \multirow[t]{2}{*}{ TLR5 } & Forward & CCAGGACCAGACGTTCAGAT & Turchetti et al. (2015) \\
\hline & Reverse & GCCCAGGAAGATGGTGTCTA & \\
\hline \multirow[t]{2}{*}{ TLR7 } & Forward & GGAAGACCCAAGGGAGAAAC & Turchetti et al. (2015) \\
\hline & Reverse & GCTGTATGCTCTGGGAAAGG & \\
\hline \multirow[t]{2}{*}{ TLR8 } & Forward & TCAGCTACAATGCACACTACTTCC & Grano et al. (2018) \\
\hline & Reverse & ACGCTTCTCAGGTCTTGCTC & \\
\hline \multirow[t]{2}{*}{ TLR9 } & Forward & CTAGTGACTGTTCAGCCGGAG & This paper \\
\hline & Reverse & CACATCAGGCTCGGGGTA & \\
\hline \multirow[t]{2}{*}{ TLR10 } & Forward & GGGGACTCTGCTAAAGGACG & This paper \\
\hline & Reverse & GCATCCTGAGATACCAGGGC & \\
\hline \multirow[t]{2}{*}{ p53 } & Forward & CGTTTGGGGTTCCTGCATTC & This paper \\
\hline & Reverse & CACTACTGTCAGAGCAGCGT & \\
\hline \multirow[t]{2}{*}{ CD14 } & Forward & GCCGGGCCTCAAGGTACT & Silva et al. (2010) \\
\hline & Reverse & TCGTGCGCAGGAAAAAGC & \\
\hline \multirow[t]{2}{*}{ MD2 } & Forward & GGGAATACGATTTTCTAAGGGACAA & Silva et al. (2010) \\
\hline & Reverse & CGGTAAAATTCAAACAAAAGAGCTT & \\
\hline \multirow[t]{2}{*}{ MYD88 } & Forward & GAGGAGATGGGCTTCGAGTA & This paper \\
\hline & Reverse & GTTCCACCAACACGTCGTC & \\
\hline \multirow[t]{2}{*}{ NF-kB/p65 } & Forward & TGTAAAGAAGCGGGACCTGG & Ishikawa et al. (2015) \\
\hline & Reverse & AGAGTTTCGGTTCACTCGGC & \\
\hline \multirow[t]{2}{*}{ STAT5 } & Forward & TTGACTCTCCTGACCGCAAC & This paper \\
\hline & Reverse & TCCGTCTACTGCTTTAGCGA & \\
\hline \multirow[t]{2}{*}{ iNOS } & Forward & AGACACACTTCACCACAAGG & Kaim et al. (2006) \\
\hline & Reverse & TGCTTGGTGGCGAAGATGAGC & \\
\hline \multirow[t]{2}{*}{ CD44 } & Forward & CAAGGCTTTCAACAGCACCC & This paper \\
\hline & Reverse & TACGTGTCGTACTGGGAGGT & \\
\hline \multirow[t]{2}{*}{ CXCR4 } & Forward & GCGTCTGGATACCTGCTCTC & This paper \\
\hline & Reverse & GATACCCGGCAGGATAAGGC & \\
\hline \multirow[t]{2}{*}{ RAD51 } & Forward & GGAGAAGGAAAGGCCATGTA & Klopfleisch and Gruber (2009) \\
\hline & Reverse & GGGTCTGGTGGTCTGTGTT & \\
\hline \multirow[t]{2}{*}{ HPRT1 } & Forward & TGCTCGAGATGTGATGAAGG & Klopfleisch and Gruber (2009) \\
\hline & Reverse & TCCCCTGTTGACTGGTCATT & \\
\hline \multirow[t]{2}{*}{ PTEN } & Forward & GTGAAGCTGTACTTCACAA & Kanae et al. (2006) \\
\hline & Reverse & CTGGGTCAGAGTCAGTGGTG & \\
\hline \multirow[t]{2}{*}{ ErbB2 } & Forward & CTGAGGGCCGATATACCTTC & Da Costa et al. (2011) \\
\hline & Reverse & TCACCTCTTGGTTGTTCAGG & \\
\hline
\end{tabular}

replicates \pm 1 standard deviation and $\Delta \Delta \mathrm{Ct}=\Delta \mathrm{Ct}$ (different passages, 34th and 40th) $-\Delta \mathrm{Ct}$ (control, 33rd passage).
Il-6 elisa

Canine IL-6 was measured in MDCK supernatants by an ELISA kit (R\&D system, cat No CA6000) 
Table 2 Gene expression in MDCK cells

\begin{tabular}{|c|c|c|}
\hline Gene & Expression & $\Delta \mathrm{Ct} \pm \mathrm{SD}$ \\
\hline GAPDH & + & HK \\
\hline HPRT1 & + & $3.6 \pm 0.2$ \\
\hline АCTB & + & $-1.81 \pm 0.6$ \\
\hline B2M & + & $0.74 \pm 0.4$ \\
\hline IL-1 $\beta$ & \pm & $19.4 \pm 1.5$ \\
\hline IL-2 & \pm & $20.0 \pm 1.2$ \\
\hline IL-4 & - & NA \\
\hline IL-5 & + & $14.6 \pm 0.5$ \\
\hline IL-6 & + & $15.8 \pm 0.6$ \\
\hline IL-8 & + & $8.5 \pm 0.7$ \\
\hline IL-10 & - & NA \\
\hline IL-12 & \pm & $21.2 \pm 0.7$ \\
\hline IL-15 & - & NA \\
\hline IL-16 & + & $14.2 \pm 0.5$ \\
\hline IL-17 & - & NA \\
\hline IL-18 & + & $16.4 \pm 0.7$ \\
\hline IL-23 & + & $10.8 \pm 0.7$ \\
\hline IL-27 & - & NA \\
\hline TNF- $\alpha$ & \pm & $20.6 \pm 0.7$ \\
\hline IFN- $\gamma$ & - & NA \\
\hline TLR1 & + & $14.2 \pm 0.5$ \\
\hline TLR2 & \pm & $19.4 \pm 1.5$ \\
\hline TLR3 & + & $9.0 \pm 0.6$ \\
\hline TLR4 & \pm & $18.4 \pm 0.6$ \\
\hline TLR5 & + & $15.8 \pm 0.7$ \\
\hline TLR7 & \pm & $20.8 \pm 2.1$ \\
\hline TLR8 & \pm & $21.0 \pm 2.3$ \\
\hline TLR9 & \pm & $20.8 \pm 1.3$ \\
\hline TLR10 & \pm & $20.6 \pm 1.8$ \\
\hline p53 & + & $12.6 \pm 1.1$ \\
\hline CD14 & + & $10.5 \pm 1.1$ \\
\hline MD2 & + & $7.0 \pm 0.6$ \\
\hline Myd88 & + & $6.6 \pm 1.2$ \\
\hline NF-kB/p65 & + & $6.3 \pm 0.7$ \\
\hline STAT-5a & + & $14.2 \pm 0.5$ \\
\hline iNOS & + & $9.8 \pm 0.8$ \\
\hline CD44 & + & $4.3 \pm 0.7$ \\
\hline CXCR4 & + & $13.2 \pm 1.3$ \\
\hline RAD51 & + & $6.1 \pm 0.8$ \\
\hline PTEN & + & $18.4 \pm 1.3$ \\
\hline ErbB2 & + & $10.0 \pm 1.4$ \\
\hline
\end{tabular}

Data are expressed as: + all samples were positive; - no positive samples were detected; \pm only some samples tested positive. GAPDH was shown to be most stable, and hence chosen to calculate the $\Delta \mathrm{Ct}$ values

$N A$ not available, $H K$ housekeeping gene according to the manufacturer's directions. IL-6 was revealed by adding $50 \mu \mathrm{L} /$ well of ortho-phenylenediamine (OPD) and $0.02 \% \quad \mathrm{H}_{2} \mathrm{O}_{2}$ as substrate. The reaction was blocked after $15 \mathrm{~min}$ of incubation by adding $50 \mu \mathrm{L} /$ well of $2 \mathrm{~N} \mathrm{H} 2 \mathrm{SO} 4$; then, plates were read spectrophotometrically at $492 \mathrm{~nm}$. Cytokine concentration was calculated from a standard curve, created using eight, twofold dilutions of canine recombinant IL-6. Data were analyzed by software Prism 5, (Graph Pad Software); the LOQ (limits of quantification) corresponded to $10 \mathrm{pg} / \mathrm{mL}$. Data were expressed as average \pm 1 standard deviation.

\section{Statistical analyses}

Data sets were submitted to a Kolmogorov-Smirnov test to check normality of distributions; significant differences within normal distributions were checked by one-way ANOVA followed by a Dunnett's test for gene expression, cytokine release and $\mathrm{Cd} 2+$ uptake. A Student's $t$ test was applied to investigate the effect of aging on gene expression. The significance threshold was set at $\mathrm{P}<0.05$ (Prism 5, GraphPad Software).

\section{Results \\ Housekeeping genes}

First, GAPDH, ACTB, HPRT1 and B2M were evaluated as possible housekeeping genes (Brinkhof et al. 2006). Results were evaluated by NormFinder, this test evaluate the stability of genes under study according to their expression ( $\rho$ ). Lower values are assigned to the most stable genes. Our results showed a good stability value for all the housekeeping genes under study; in particular, B2M showed $\mathrm{P}=0.00175$, GAPDH $\mathrm{P}=0.00174, \mathrm{~B}-\mathrm{ACT} \quad \mathrm{P}=0.00476$ and HPRT1 $\mathrm{P}=0.00233$. Therefore, GAPDH was chosen to calculate the $\Delta \mathrm{Ct}$ values.

\section{Basal gene expression}

We demonstrated the expression of all the genes under study except for IL-4, IL-10, IL-15, IL-17, IL-27 and IFN- $\gamma$ (Table 2). Concerning TLRs, MDCK expressed TLR1, TLR3 and TLR5 in all samples, while for the other TLRs we obtained the following results: TLR2 was expressed in $96.6 \%$ of samples; TLR4 in $93.3 \%$; 
TLR7 in $80 \%$; TLR8 in $66.6 \%$; TLR9 in $96.6 \%$; finally, TLR10 was expressed in $86.6 \%$ of analysed samples. NF-kB/p65, MyD88, CD14 and MD2 were expressed in all samples (Table 2). As for cytokines, we showed expression of IL5, IL6, IL8, IL16, IL18 and IL23 in all samples (Table 2). IL1- $\beta$ and IL-2 were expressed in $93.3 \%$ of samples; IL-12 tests indicated expression in $86.6 \%$ of samples; TNF- $\alpha$ was unexpressed in $23.3 \%$. Concerning the other genes under study, we observed the expression of INOS, STAT-5a, p53, RAD51, CXCR4, ErbB2, PTEN and CD44 in all the test samples (Table 2).

Modulation of gene expression at different cell passages and effect of cell aging

Our results showed modulation of gene expression at the 34th and 40th passages (Fig. 1). In particular, at passage 34 we observed an increase of TLR7 and a decrease of B2M gene expression. Regarding the 40th passage, IL-2, IL-5, IL-12, IL-18, TLR2, TLR7, TLR9, TLR10, p53, CXCR4, MD2 and HPRT1 gene expression was up-regulated. On the contrary, IL-6, TLR3 and TLR5 were down-regulated. After $24 \mathrm{~h}$ aged cells, at passage 40, showed decrease of NF-kB/ p65 and B-ACT gene expression. MyD88, IL-18 and CXCR4 were not modulated (data not shown) while other genes under study were up-regulated (Fig. 2; $\mathrm{P}<0.05)$.

Cadmium uptake and gene expression modulation

Our data showed a significant increase of intracellular $\mathrm{Cd} 2+$ after $24 \mathrm{~h}$ of exposure with respect to the levels at $1 \mathrm{~h}$. In particular, we observed $0.08 \%, 0.11 \%$ and $1.1 \%$ $\mathrm{Cd} 2+$ absorption after 1,3 and $24 \mathrm{~h}$ of exposure, respectively, using $20 \mu \mathrm{M} \mathrm{Cd} 2+(4 \mu \mathrm{g}$ of $\mathrm{Cd} 2+$ / $10^{6}$ cells; Fig. 3). $20 \mu \mathrm{M} \mathrm{Cd} 2+$ after $3 \mathrm{~h}$ of exposure caused up-regulation of IL-1B, IL-6, IL-8, INOS, TLR1, TLR3, TLR5 and TLR9 gene expression. On the contrary, CD14 was down-regulated (Fig. 3). After $24 \mathrm{~h}$ of exposure we observed up-regulation of IL-18, Nf-kB/p65 and MYD88; at the same time, INOS, IL-1B, MD2, TLR5 and TLR9 were down-regulated. Other genes under study were not significantly modulated. Regarding IL-6 release, we observed a significant increase of this cytokine in cell supernatants after $3 \mathrm{~h}$ $(54 \pm 3.3 \mathrm{pg} / \mathrm{ml})$ and $24 \mathrm{~h}(51 \pm 6.8 \mathrm{pg} / \mathrm{ml})$ of $\mathrm{Cd} 2+$ exposure with respect to untreated cells $(<10 \mathrm{pg} / \mathrm{ml})$.

\section{Effects of LPS treatment}

Treatment with $1 \mu \mathrm{g} / \mathrm{mL}$ LPS for $3 \mathrm{~h}$ caused upregulation of MyD88 gene expression; at the same

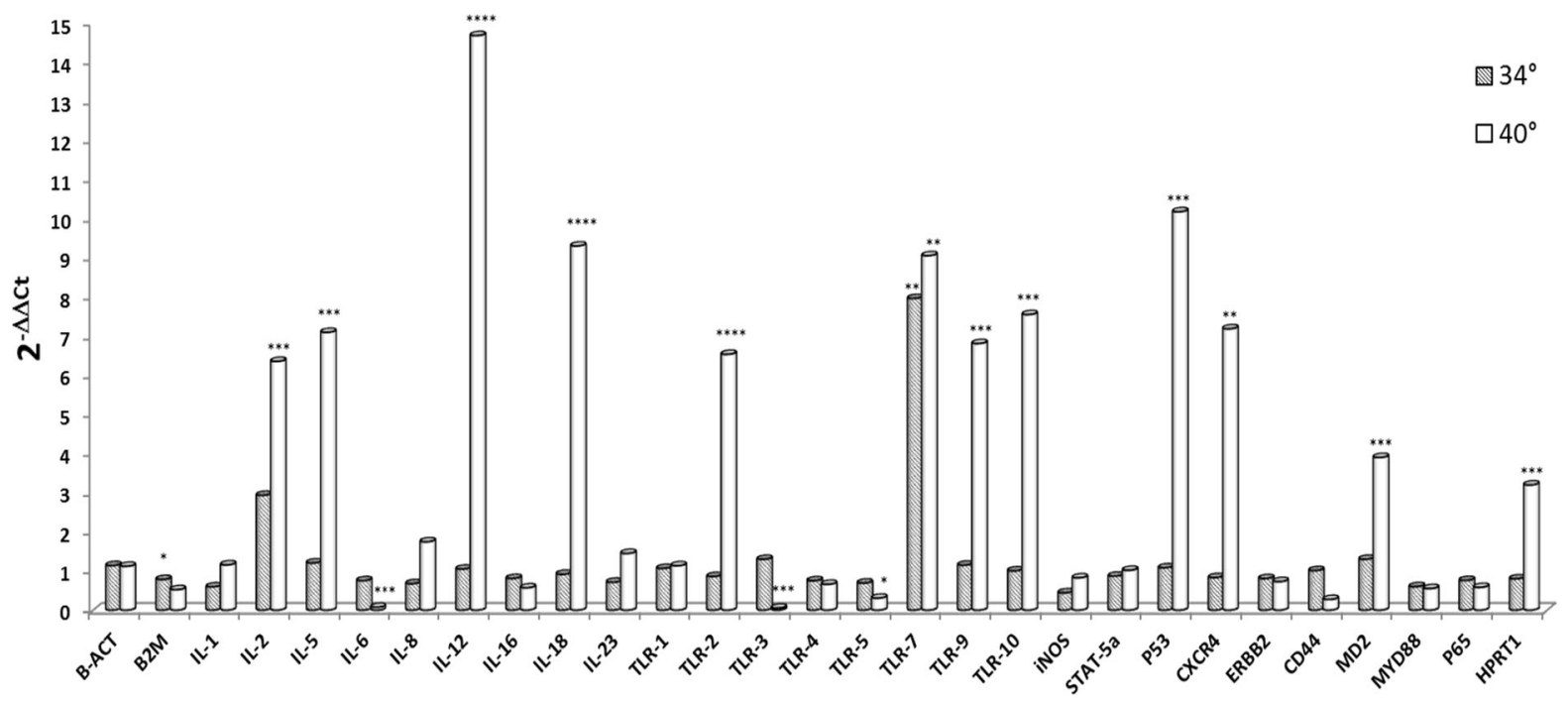

Fig. 1 Gene expression at different passage levels. Data are expressed as $2^{-\Delta \Delta \mathrm{Ct}}$ where $\Delta \mathrm{Ct}=\mathrm{Ct}$ (target gene) $-\mathrm{Ct}$ (housekeeping); values are the mean of three test replicates \pm 1 standard deviation and $\Delta \Delta \mathrm{Ct}=\Delta \mathrm{Ct} \quad$ (34th or 40th passage) $-\Delta \mathrm{Ct}$ (control, 33rd passage). Negative samples were given a $\mathrm{Ct} 38$ fictitious value. Asterisks indicate significant differences between controls and different passages cells: $* \mathrm{P}<0.05, * * \mathrm{P}<0.01$ and $* * * \mathrm{P}<0.001$ 


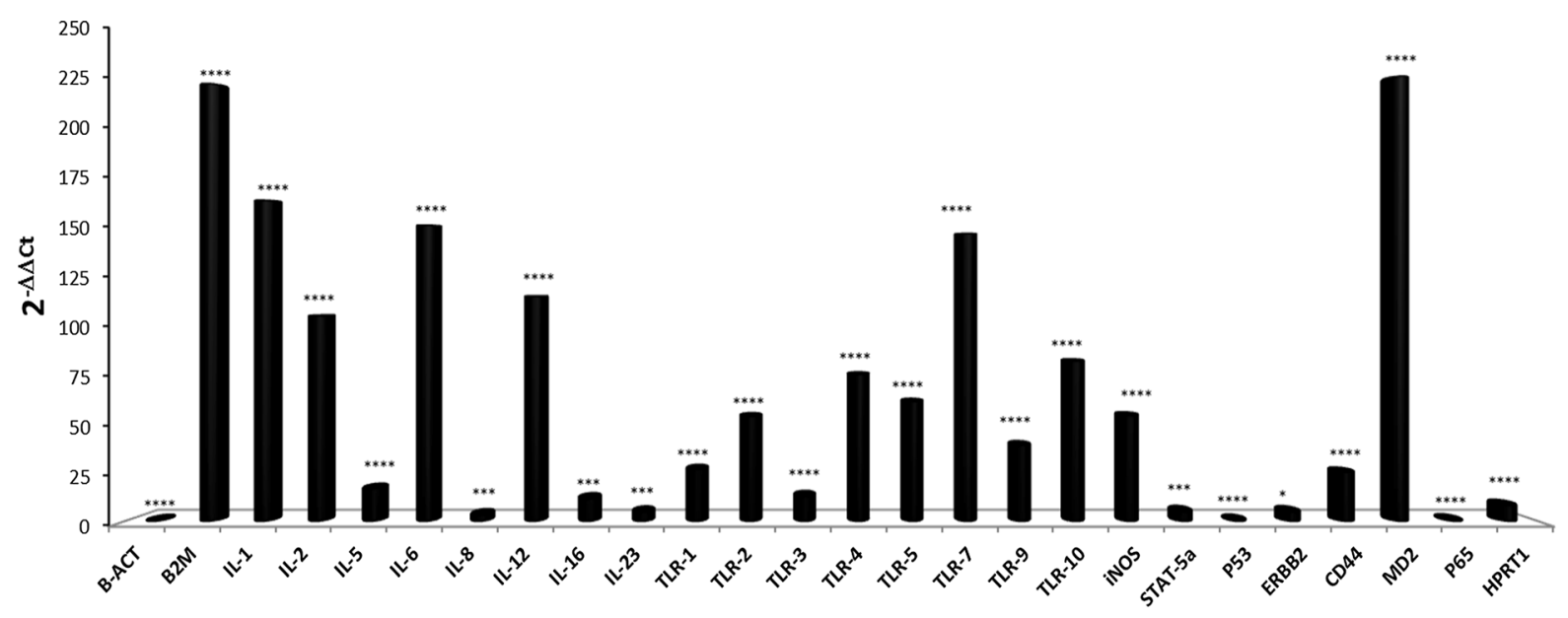

Fig. 2 Modulation of gene expression due to cell aging. Data are expressed as $2^{-\Delta \Delta \mathrm{Ct}}$ where $\Delta \mathrm{Ct}=\mathrm{Ct}$ (target gene) $-\mathrm{Ct}$ (housekeeping); values are the mean of three test replicates \pm 1 standard deviation and $\Delta \Delta \mathrm{Ct}=\Delta \mathrm{Ct}$ (40th passage at confluence plus $24 \mathrm{~h}$ of incubation at $37^{\circ} \mathrm{C}$ ) $-\Delta \mathrm{Ct}$ (control 40th passage

time, INOS, IL-1B, CD14, TLR5 and TLR9 were down-regulated (Fig. 4). After 24 of treatment no significant modulation of gene expression was observed (Fig. 4). Concerning IL-6 release, all samples of the LPS study tested negative (IL-6 $<10 \mathrm{pg} / \mathrm{ml}$; Data not shown).

\section{Discussion}

Madin-Darby Canine Kidney (MDCK) is a continuous cell line of distal tubules of canine kidney widely used for different purposes, such as isolation of influenza viruses, production of flu vaccines, pathogenicity studies of bacterial strains, cytotoxicity tests. Although several studies showed satisfactory results in MDCK cells for these purposes, none of them described their characteristics in terms of both gene expression and involvement in the innate immune response. Therefore, our study focused on the basal levels of protein release and gene expression in this cell line under physiological conditions and after exposure to diverse stressors. Accordingly, we developed a RT-qPCR to evaluate the expression of a selected group of 41 genes coding for molecules of different typology and function. Our results demonstrated the expression of all the genes under study with the exception of IL-4, IL-10, IL-15, IL-17, IL-27 and at confluence). Negative samples were given a $\mathrm{Ct} 38$ fictitious value. Asterisks indicate significant differences between control and aging cells evaluated by Student's t-test. $* \mathrm{P}<0.05$, $* * * \mathrm{P}<0.001$ and $* * * * \mathrm{P}<0.0001$

IFNG; this is in agreement with other studies that reported no expression of these genes in epithelial cells (Bianchi 2007; Groeger and Meyle 2019). We also investigated the basal expression level of TLRs, a family of Pattern Recognition Receptors (PRRs), expressed by many cell types, in order to recognize microorganisms (e.g. bacteria, viruses and fungi) and to induce the innate immune response (Velloso et al. 2015). The expression in MDCK of these molecules is in line with the routine use of this cell line: evaluation of the virulence of some bacterial strains, including bacterial penetration, adhesion and cytotoxicity (Chou et al. 2016; Lin et al. 2017). The expression in all samples of p65, one of the major members of the NF$\mathrm{kB}$ protein family, along with MyD88, IL-1 $\beta$, IL-6, IL-8 and IL-16, implies the ability of this cell line to mount an inflammatory response. This assumption is confirmed by our results. In particular, $\mathrm{Cd} 2+$ exposure caused an inflammatory response characterized by upregulation of genes expression and IL-6 release; this was associated to $\mathrm{Cd} 2+$ uptake, in agreement with previous studies conducted on Enterocytes (Razzuoli et al. 2018). MDCK cells showed the ability to absorb low levels of $\mathrm{Cd} 2+$, causing an innate immune response, although this cell line is more resistant to $\mathrm{Cd} 2+$ exposure, compared with other cell lines like LLC-PK1 (Bonham et al. 2003). Also, a previous study showed that $\mathrm{Cd} 2+$ treatments at concentrations 
(1) Cd2+ uptake

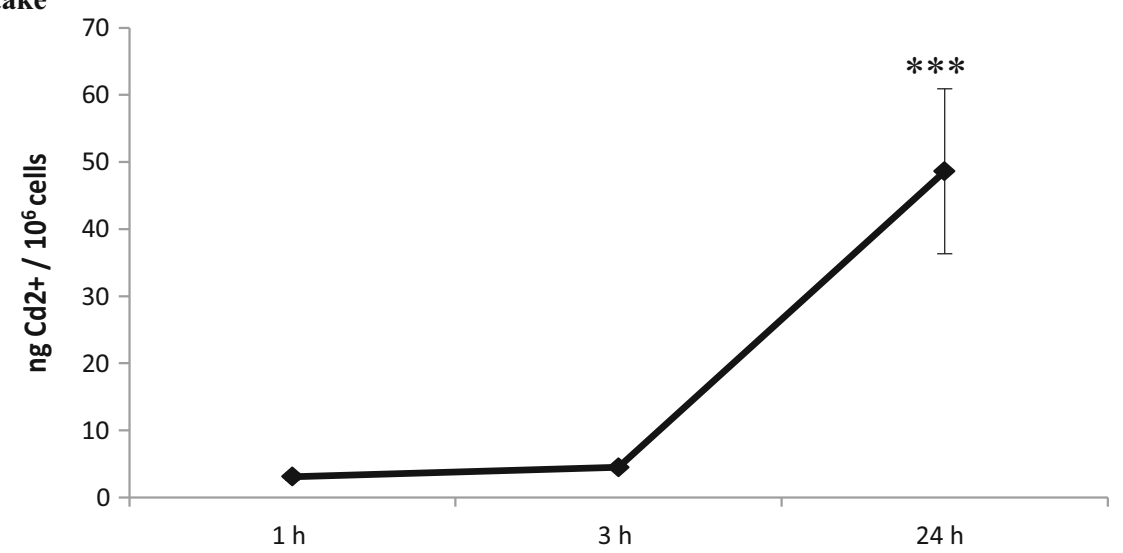

(2) Modulation of gene expression

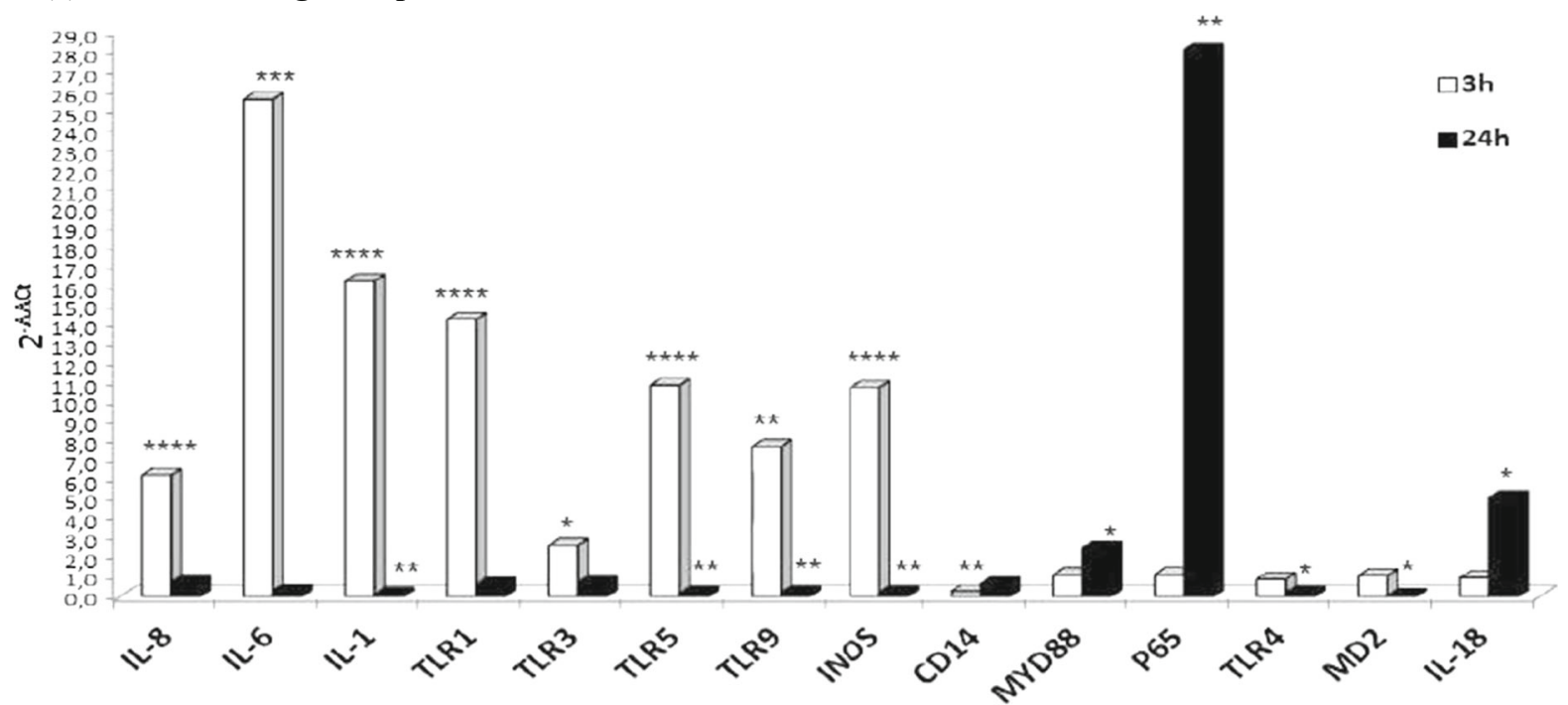

Fig. $3 \mathrm{Cd} 2+$ treatment. $\mathrm{Cd} 2+$ uptake into MDCK cells was measured after 1, 3 and 24 h of exposure. Cells were treated with $20 \mu \mathrm{M}$ Cadmium $\left(4 \mu \mathrm{g} / 10^{6}\right.$ cells); then, intracellular concentration of $\mathrm{Cd} 2+$ was measured at different times of exposure. Data are shown as mean \pm 1 SD. Asterisk indicate significant differences $(\mathrm{P}<0.0001)$ with respect to $1 \mathrm{~h}$ of exposure, determined by one-way ANOVA. Gene expression was measured after treatment of MDCK cells with $20 \mu \mathrm{M}$ cadmium

equal to or greater than $10 \mu \mathrm{M}$ (LLC-PK1) or $25 \mu \mathrm{M}$ (MDCK) reduce cell vitality and induce cell death (Bonham et al. 2003).

The basal levels of IL-2 and IL-5, involved in the immune response, suggest the possibility to use this cell line in interaction studies between microbial agents and host (Ma et al. 2015; Krishnamoorthy et al. 2016). In our study, the exposure of MDCK to Cd2+ caused up-regulation of iNOS, TLR1, TLR3, TLR5 for 3 and $24 \mathrm{~h}$ at $37{ }^{\circ} \mathrm{C}$ in $5 \% \mathrm{CO}_{2}$. Data are expressed as $2^{-\Delta \Delta \mathrm{Ct}}$ where $\Delta \mathrm{Ct}=\mathrm{Ct}$ (target gene) $-\mathrm{Ct}$ (housekeeping); values are the mean of three test replicates \pm 1 standard deviation and $\Delta \Delta \mathrm{Ct}=\Delta \mathrm{Ct}(\mathrm{Cd}$ treatment $)-\Delta \mathrm{Ct}$ (untreated control). Negative samples were given a $\mathrm{Ct} 38$ fictitious value. Asterisks indicate significant differences: $* \mathrm{P}<0.05, \quad * * \mathrm{P}<0.01$, $* * * \mathrm{P}<0.001$ and $* * * * \mathrm{P}<0.0001$

and TLR9 gene expression after $3 \mathrm{~h}$ of exposure. The genes that are expressed in response to the activation of TLRs encode important proteins at various levels of the innate immune response, including not only cytokines, but also proteins involved in the mechanisms of bacterial killing, such as the inducible nitric oxide synthetase iNOS (Tsutsuki et al. 2012). This response could ease the replication of viral agents in MDCK cells; in this respect, Checconi et al. (2013) 


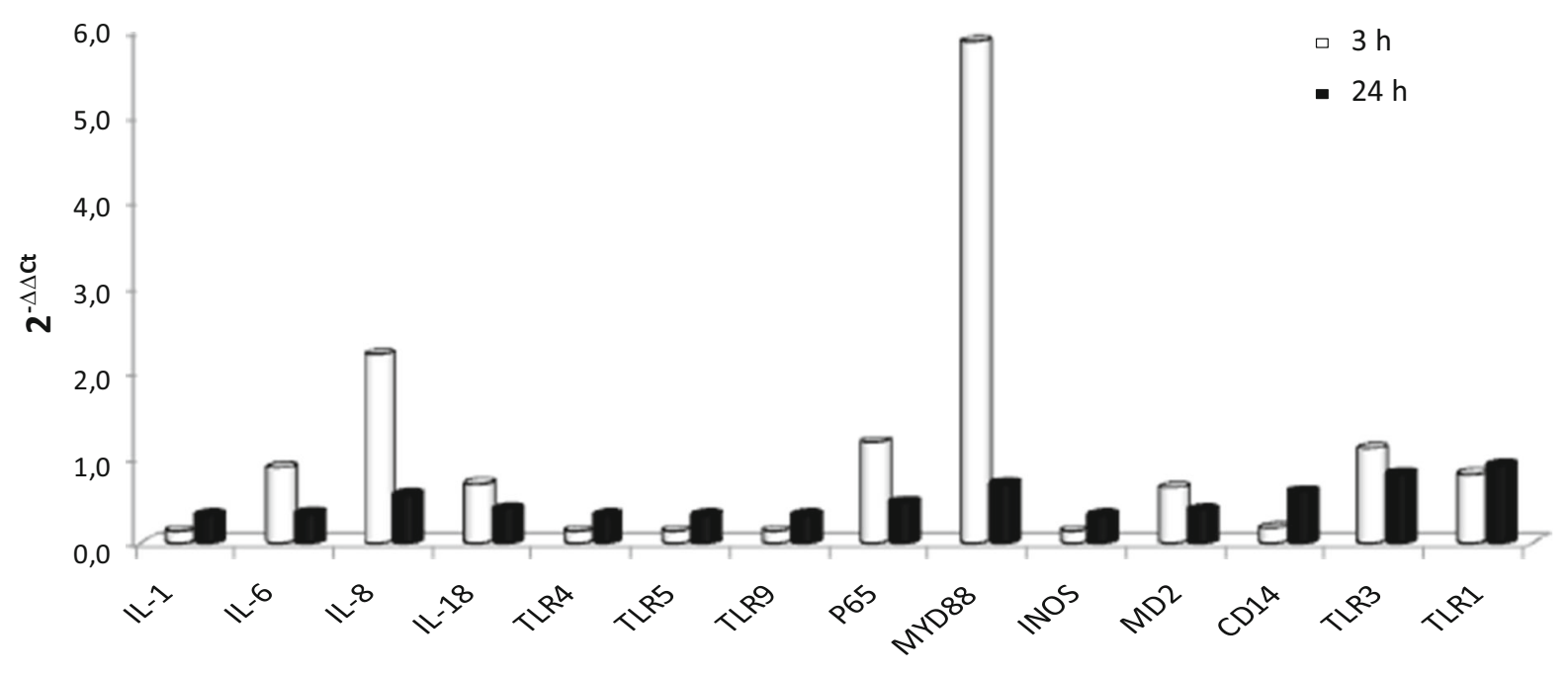

Fig. 4 Effect of LPS treatment. Gene expression was measured after treatment of MDCK cells with $1 \mu \mathrm{g} / \mathrm{mL} \mathrm{LPS} \mathrm{for} 3$ and $24 \mathrm{~h}$ at $37{ }^{\circ} \mathrm{C}$ in $5 \% \quad \mathrm{CO}_{2}$. Data are expressed as $2^{-\Delta \Delta \mathrm{Ct}}$ where $\Delta \mathrm{Ct}=\mathrm{Ct}$ (target gene) $-\mathrm{Ct}$ (housekeeping), values are the mean of three test replicates \pm 1 standard deviation and

demonstrated that the exposure to low levels of cadmium $(1-50 \mu \mathrm{M})$ increased influenza virus replication in a dose-dependent manner. Moreover, the exposure to LPS caused in this study a downregulation of iNOS, CD14, TLR5 and TLR9, which confirms the ability of cells to react to both infectious and non-infectious stressors.

Treatment with LPS caused no significant effects in terms of TNF- $\alpha$, IL- $1 \beta$, and IL-6 gene expression and protein release in agreement with our previous study (Razzuoli et al. 2013). However, these results differ from data obtained on myeloid cells like human macrophages and monocytes, where LPS causes early pro-inflammatory responses through TLR4/NF-kB signaling (Petes et al. 2018). The absence of IL-1 $\beta$ and IL- 6 responses to LPS in MDCK cells could be accounted for by a form of constitutive endotoxin tolerance (Lotz et al. 2006) in these epithelial cells.

Concerning the $\mathrm{Cd} 2+$ treatment, we found modulation of gene expression and IL-6 protein release in MDCK cells as a function of time. In particular, we observed at different times of incubation with $20 \mu \mathrm{M}$ $\mathrm{Cd} 2+$ the modulation of some important pro-inflammatory cytokines and chemokines (IL-8, IL-6, IL-1 $\beta$, IL-18), and transcription factor genes (NF-kB/p65). Similar results were obtained in IPEC-J2 (Razzuoli et al. 2018) and Caco-2 cells, in which Hyun et al.
$\Delta \Delta \mathrm{Ct}=\Delta \mathrm{Ct}(\mathrm{Cd}$ treatment $)-\Delta \mathrm{Ct}$ (untreated control). Negative samples were given a $\mathrm{Ct} 38$ fictitious value. Asterisks indicate significant differences: $* \mathrm{P}<0.05, \quad * * \mathrm{P}<0.01$, $* * * \mathrm{P}<0.001$ and $* * * * \mathrm{P}<0.0001$

(2007) demonstrated the activation of an inflammatory response through the NF-kb pathway. These data outline the negative repercussions of lab contamination by LPS or $\mathrm{Cd} 2+$ on experiments carried out on these cells.

In this study, we also demonstrated the effect of cell passages on MDCK gene expression; this is a very important issue that must be considered not only during gene expression studies but above all in host/pathogen interaction studies because both passage level and aging can alter TLRs and cytokine gene expression.

\section{Conclusion}

In conclusion, our study showed the constitutive expression of genes involved in the innate immune response and cell defense in MDCK cells. Albeit our findings refer to two major stressors only, we confirmed the capacity of this cell line to respond to infectious and non-infectious stressors in terms of gene expression and cytokine release. Finally, this data suggests the possibility of using this cell line as a model in studies of host/pathogen interaction and response to environmental pollutants. 
Acknowledgements The authors want to thank Mrs. C. Citati for the skilful technical assistance; her work is gratefully acknowledged. This study was supported by the Italian Ministry of Health, Grant RC15C08.

\section{Compliance with ethical standards}

Conflict of interest The authors declare that they have no conflict of interest.

\section{References}

Bernard A (2008) Cadmium and its adverse effects on human health. Indian J Med Res 128:557-564

Bianchi I (2007) Citochine e Interferoni. Farmacologia e Clinica, 1st edn. Nuova IPSA, Palermo

Bonham RT, Fine MR, Pollock FM, Shelden EA (2003) Hsp27, Hsp70, and metallothionein in MDCK and LLC-PK1 renal epithelial cells: effects of prolonged exposure to cadmium. Toxicol Appl Pharmacol 191:63-73

Brinkhof B, Spee B, Rothuizen J, Penning LC (2006) Development and evaluation of canine reference genes for accurate quantification of gene expression. Anal Biochem 356:36-43 Epub 2006 Jun 15

Cavalcanti AS, Ribeiro-Alves M, Pereira L, Mestre GL, Ferreira AB, Morgado FN, Boité MC, Cupolillo E, Moraes MO, Porrozzi R (2015) Parasite load induces progressive spleen architecture breakage and impairs cytokine mRNA expression in Leishmania infantum-naturally infected dogs. PLoS ONE 10:e0123009. https://doi.org/10.1371/ journal.pone.0123009

Checconi P, Sgarbanti R, Celestino I, Limongi D, Amatore D, Iuvara A, Alimonti A, Garaci E, Palamara AT, Nencioni L (2013) The environmental pollutant cadmium promotes influenza virus replication in MDCK cells by altering their redox state. Int J Mol Sci 19:4148-4162. https://doi.org/10. 3390/ijms 14024148

Choi EW, Shin IS, Bhang DH, Lee DH, Bae BK, Kang MS, Kim DY, Hwang CY, Lee CW, Youn HY (2006) Hormonal change and cytokine mRNA expression in peripheral blood mononuclear cells during the development of canine autoimmune thyroiditis. Clin Exp Immunol 146:101-108

Chou HI, Chen KS, Wang HC, Lee WM (2016) Effects of cranberry extract on prevention of urinary tract infection in dogs and on adhesion of Escherichia coli to Madin-Darby canine kidney cells. Am J Vet Res 77:421-427. https://doi. org/10.2460/ajvr.77.4.421

da Costa A, Oliveira JT, Gärtner F, Kohn B, Gruber AD, Klopfleisch R (2011) Potential markers for detection of circulating canine mammary tumor cells in the peripheral blood. Vet J. 190:165-168. https://doi.org/10.1016/j.tvjl. 2010.09.027

Dukes JD, Whitley P, Chalmers AD (2012) The PIKfyve inhibitor YM201636 blocks the continuous recycling of the tight junction proteins Claudin-1 and Claudin-2 in MDCK cells. PLoS ONE 7:e28659. https://doi.org/10.1371/ journal.pone.0028659

Gorbet MB, Sefton MV (2005) Endotoxin: the uninvited guest. Biomaterials 26:6811-6817
Grano FG, Dos S, Silva JE, Melo GD, de Souza MS, Lima VMF, Machado GF (2018) Toll-like receptors and cytokines in the brain and in spleen of dogs with visceral leishmaniosis. Vet Parasitol 253:30-38. https://doi.org/10.1016/j.vetpar. 2018.02.030

Gregersen JP, Schmitt HJ, Trusheim H, Bröker M (2011) Safety of MDCK cell culture-based influenza vaccines. Future Microbiol. 6:143-152. https://doi.org/10.2217/fmb.10.161

Groeger S, Meyle J (2019) Oral mucosal epithelial cells. Front Immunol. 14:208. https://doi.org/10.3389/fimmu.2019. 00208

Hosein S, Rodríguez-Cortés A, Blake DP, Allenspach K, Alberola J, Solano-Gallego L (2015) Transcription of tolllike receptors 2, 3, 4 and 9, FoxP3 and Th17 cytokines in a susceptible experimental model of canine leishmania infantum infection. PLoS ONE 10:e0140325. https://doi. org/10.1371/journal.pone.0140325

Hyun JS, Satsu H, Shimizu M (2007) Cadmium induces interleukin-8 production via NF-kappaB activation in the human intestinal epithelial cell, Caco-2. Cytokine 37:26-34

Ishikawa S, Takemitsu H, Li G, Mori N, Yamamoto I, Arai T (2015) Molecular characterization of dog and cat p65 subunits of NF-kappaB. Res Vet Sci 99:145-148. https:// doi.org/10.1016/j.rvsc.2015.02.009

Jalilian I, Peranec M, Curtis BL, Seavers A, Spildrejorde M, Sluyter V, Sluyter R (2012) Activation of the damage-associated molecular pattern receptor $\mathrm{P} 2 \mathrm{X} 7$ induces interleukin- $1 \beta$ release from canine monocytes. Vet Immunol Immunopathol 149:86-91. https://doi.org/10.1016/j. vetimm.2012.05.004

Kaim U, Moritz A, Failing K, Baumgärtner W (2006) The regression of a canine Langerhans cell tumour is associated with increased expression of IL-2, TNF-alpha, IFN-gamma and iNOS mRNA. Immunology 4:472-482

Kanae Y, Endoh D, Yokota H, Taniyama H, Hayashi M (2006) Expression of the PTEN tumor suppressor gene in malignant mammary gland tumors of dogs. Am J Vet Res. 67:127-133

Kim JW, Lee JH, Lyoo YS, Jung DI, Park HM (2013) The effects of topical mesenchymal stem cell transplantation in canine experimental cutaneous wounds. Vet Dermatol 24:242-253. https://doi.org/10.1111/vde.12011

Klopfleisch R, Gruber AD (2009) Derlin-1 and stanniocalcin-1 are differentially regulated in metastasizing canine mammary adenocarcinomas. J Comp Pat. 141:113-120

Krishnamoorthy P, Sengupta PP, Das S, Lig M, Shome BR, Rahman H (2016) Cytokine gene expression and pathology in mice experimentally infected with different isolates of Trypanosoma evansi. Exp Parasitol 170:168-176. https:// doi.org/10.1016/j.exppara.2016.09.019

Kurata K, Iwata A, Masuda K, Sakaguchi M, Ohno K, Tsujimoto $\mathrm{H}$ (2004) Identification of CpG oligodeoxynucleotide sequences that induce IFN-gamma production in canine peripheral blood mononuclear cells. Vet Immunol Immunopathol 102:441-450

Lin Y, Wharton SA, Whittaker L, Dai M, Ermetal B, Lo J, Pontoriero A, Baumeister E, Daniels RS, McCauley JW (2017) The characteristics and antigenic properties of recently emerged subclade 3 C.3a and 3C.2a human influenza A(H3N2) viruses passaged in MDCK cells. Influenza 
Other Respir Viruses 11:263-274. https://doi.org/10.1111/ irv. 12447

Lotz M, Gütle D, Walther S, Ménard S, Bogdan C, Hornef MW (2006) Postnatal acquisition of endotoxin tolerance in intestinal epithelial cells. J Exp Med 203:973-984

Luevano J, Damodaran C (2014) A review of molecular events of cadmium-induced carcinogenesis. J Environ Pathol Toxicol Oncol 33:183-194

Ma G, Tan Y, Hu L, Luo Y, Zhu H, Zhou R (2015) Short communication: experimental toxocarosis in Chinese Kun Ming mice: dose-dependent larval distribution and modulation of immune responses. Res Vet Sci 103:16-19. https://doi.org/10.1016/j.rvsc.2015.09.002

Maret W, Moulis JM (2013) The bioinorganic chemistry of cadmium in the context of its toxicity. Met Ions Life Sci. 11:1-29. https://doi.org/10.1007/978-94-007-5179-8_1

Menezes-Souza D, Corrêa-Oliveira R, Guerra-Sá R, Giunchetti RC, Teixeira-Carvalho A, Martins-Filho OA, Oliveira GC, Reis AB (2011) Cytokine and transcription factor profiles in the skin of dogs naturally infected by Leishmania (Leishmania) chagasi presenting distinct cutaneous parasite density and clinical status. Vet Parasitol 177:39-49

Milnerowicz H, Ściskalska M, Dul M (2015) Pro-inflammatory effects of metals in persons and animals exposed to tobacco smoke. J Trace Elem Med Biol 29:1-10. https://doi.org/10. 1016/j.jtemb.2014.04.008

Nascimento MS, Albuquerque TD, Nascimento AF, Caldas IS, Do-Valle-Matta MA, Souto JT, Talvani A, Bahia MT, Galvão LM, Câmara AC, Guedes PM (2015) Impairment of interleukin-17A expression in canine visceral leishmaniosis is correlated with reduced interferon- $\gamma$ and inducible nitric oxide synthase expression. J Comp Pathol 153:197-205

Ogrodnik M, Salmonowicz H, Gladyshev VN (2019) Integrating cellular senescence with the concept of damage accumulation in aging: relevance for clearance of senescent cells. Aging Cell 18:e12841. https://doi.org/10.1111/acel. 12841

Peeters D, Peters IR, Farnir F, Clercx C, Day MJ (2005) Realtime RT-PCR quantification of mRNA encoding cytokines and chemokines in histologically normal canine nasal, bronchial and pulmonary tissue. Vet Immunol Immunopathol 104:195-204

Peletto S, Bertuzzi S, Campanella C, Modesto P, Maniaci MG, Bellino C, Ariello D, Quasso A, Caramelli M, Acutis PL (2011) Evaluation of internal reference genes for quantitative expression analysis by real-time PCR in ovine whole blood. Int J Mol Sci 12:7732-7747. https://doi.org/10. 3390/ijms 12117732

Petes C, Mintsopoulos V, Finnen RL, Banfield BW, Gee K (2018) The effects of CD14 and IL-27 on induction of endotoxin tolerance in human monocytes and macrophages. J Biol Chem. https://doi.org/10.1074/jbc.ra118. 003501

Poltorak A, He X, Smirnova I, Liu MY, Van Huffel C, Du X, Birdwell D, Alejos E, Silva M, Galanos C, Freudenberg M, Ricciardi-Castagnoli P, Layton B, Beutler B (1998) Defective LPS signaling in $\mathrm{C} 3 \mathrm{H} / \mathrm{HeJ}$ and C57BL/10ScCr mice: mutations in Tlr4 gene. Science 282:2085-2088
Rathinam VAK, Zhao Y, Shao F (2019) Innate immunity to intracellular LPS. Nat Immunol 20:527-533. https://doi. org/10.1038/s41590-019-0368-3

Razzuoli E, Villa R, Sossi E, Amadori M (2011) Reverse transcription real-time PCR for detection of porcine interferon $\alpha$ and $\beta$ genes. Scand J Immunol 74:412-418. https://doi. org/10.1111/j.1365-3083.2011.02586.x

Razzuoli E, Villa R, Amadori M (2013) IPEC-J2 cells as reporter system of the anti-inflammatory control actions of interferon-alpha. J Interferon Cytokine Res 33:597-605. https://doi.org/10.1089/jir.2012.0127

Razzuoli E, Villa R, Ferrari A, Amadori M (2014) A pig tonsil cell colture model for evaluating oral, low-dose INF- $\alpha$ treatments. Vet Immunol Immunpathol 160:244-254. https://doi.org/10.1016/j.vetimm.2014.05.011

Razzuoli E, Mignone G, Lazzara F, Vencia W, Ferraris M, Masiello L, Vivaldi B, Ferrari A, Bozzetta E, Amadori M (2018) Impact of cadmium exposure on swine enterocytes. Toxicol Lett 287:92-99. https://doi.org/10.1016/j.toxlet. 2018.02.005

Rusanov AL, Smirnova AV, Poromov AA, Fomicheva KA, Luzgina NG, Majouga AG (2015) Effects of cadmium chloride on the functional state of human intestinal cells. Toxicol In Vitro 29(5):1006-1011

Sauter SN, Allenspach K, Gaschen F, Gröne A, Ontsouka E, Blum JW (2005) Cytokine expression in an ex vivo culture system of duodenal samples from dogs with chronic enteropathies: modulation by probiotic bacteria. Domest Anim Endocrinol 29:605-622

Schwarz H, Schmittner M, Duschl A, Horejs-Hoeck J (2014) Residual endotoxin contaminations in recombinant proteins are sufficient to activate human $\mathrm{CD} 1 \mathrm{c}+$ dendritic cells. PLoS ONE 9:e113840. https://doi.org/10.1371/ journal.pone. 0113840

Selvarajah GT, Bonestroo FAS, Timmermans Sprang EPM, Kirpensteijn J, Mol JA (2017) Reference gene validation for gene expression normalization in canine osteosarcoma: a geNorm algorithm approach. BMC Vet Res. 13:354. https://doi.org/10.1186/s12917-017-1281-3

Silva E, Leitão S, Henriques S, Kowalewski MP, Hoffmann B, Ferreira-Dias G, da Costa LL, Mateus L (2010) Gene transcription of TLR2, TLR4, LPS ligands and prostaglandin synthesis enzymes are up-regulated in canine uteri with cystic endometrial hyperplasia-pyometra complex. J Reprod Immunol 84:66-74. https://doi.org/10.1016/ j.jri.2009.10.004

Sok SPM, Ori D, Nagoor NH, Kawai T (2018) Sensing self and non-self DNA by innate immune receptors and their signaling pathways. Crit Rev Immunol 38:279-301. https:// doi.org/10.1615/CritRevImmunol.2018026540

Tan SY, Praveena SM, Abidin EZ, Cheema MS (2016) A review of heavy metals in indoor dust and its human health-risk implications. Rev Environ Health 3:447-456. https://doi. org/10.1515/reveh-2016-0026

Tchounwou PB, Yedjou CG, Patlolla AK, Sutton DJ (2012) Heavy metal toxicity and the environment. Exp Suppl 101:133-164. https://doi.org/10.1007/978-3-7643-83404_6

Tsutsuki H, Yahiro K, Suzuki K, Suto A, Ogura K, Nagasawa S, Ihara H, Shimizu T, Nakajima H, Moss J, Noda M (2012) Subtilase cytotoxin enhances Escherichia coli survival in 
macrophages by suppression of nitric oxide production through the inhibition of NF- $\kappa \mathrm{B}$ activation. Infect Immun 80:3939-3951. https://doi.org/10.1128/IAI.00581-12

Turchetti AP, da Costa LF, Romão Ede L, Fujiwara RT, da Paixão TA, Santos RL (2015) Transcription of innate immunity genes and cytokine secretion by canine macrophages resistant or susceptible to intracellular survival of Leishmania infantum. Vet Immunol Immunopathol 163:67-76

Turner A (2019) Cadmium pigments in consumer products and their health risks. Sci Total Environ 657:1409-1418. https://doi.org/10.1016/j.scitotenv.2018.12.096

Vanherberghen M, Bureau F, Peters IR, Day MJ, Clercx C, Peeters D (2012) Analysis of gene expression in canine sino-nasal aspergillosis and idiopathic lymphoplasmacytic rhinitis: a transcriptomic analysis. Vet Microbiol 157:143-151. https://doi.org/10.1016/j.vetmic.2011.12. 009

Velloso LA, Folli F, Saad MJ (2015) TLR4 at the crossroads of nutrients, gut microbiota, and metabolic inflammation. Endocr Rev 36:245-271. https://doi.org/10.1210/er.20141100

Venugopal B, Luckey TP (1975) Toxicology of non-radioactive heavy metals and their salts. Environ Qual Saf Suppl 4:104-114

Publisher's Note Springer Nature remains neutral with regard to jurisdictional claims in published maps and institutional affiliations. 